Article

\title{
Valuation of Trust in Government: The Wellbeing Valuation Approach
}

\author{
Savinee Suriyanrattakorn ${ }^{1}$ (D) and Chia-Lin Chang ${ }^{1,2, *(D)}$ \\ 1 Department of Applied Economics, National Chung Hsing University, South District, \\ Taichung City 402204, Taiwan; savinee.suri@gmail.com \\ 2 Department of Finance, National Chung Hsing University, South District, Taichung City 402204, Taiwan \\ * Correspondence: changchialin@email.nchu.edu.tw
}

Citation: Suriyanrattakorn, S.;

Chang, C.-L. Valuation of Trust in Government: The Wellbeing Valuation Approach. Sustainability 2021, 13, 11000. https://doi.org/ $10.3390 /$ su131911000

Academic Editor: Franklin G. Mixon

Received: 30 August 2021

Accepted: 1 October 2021

Published: 4 October 2021

Publisher's Note: MDPI stays neutral with regard to jurisdictional claims in published maps and institutional affiliations.

Copyright: (c) 2021 by the authors. Licensee MDPI, Basel, Switzerland. This article is an open access article distributed under the terms and conditions of the Creative Commons Attribution (CC BY) license (https:/ / creativecommons.org/licenses/by/ $4.0 /)$.

\begin{abstract}
Subjective wellbeing maximization is a possible goal of government or public policies, and it is often considered the goal of individual life. This paper proposes an estimation using the Wellbeing Valuation Approach (WVA) to estimate the monetized effect of trust in government. Using a cross-country panel data set for 97 countries in the period from 2011 to 2019, we arrive at three main findings. First, there is a positive relationship between trust in national government and average life satisfaction. Second, trust in the national government has a global median value of Intl\$ 5649 per person a year in foregone income. Third, trust affects life satisfaction directly as well as indirectly through per capita GDP. This indirect effect is considered relatively small compared to the direct effect, being approximately six times smaller. This study contributes to the policy evaluation literature by providing an evaluation of trust in government to be used as a proxy to plan future investment or policy assessment.
\end{abstract}

Keywords: life satisfaction; trust in government; confidence in national government; subjective wellbeing; wellbeing valuation approach

\section{Introduction}

Trust in government is identified as an essential element that determines the government's efficiency and effectiveness; with less trust in government, enforcement and transaction costs tend to increase because of uncertainties [1]. Empirical research has shown that trust in government affects various social and economic indicators, such as inequality, confidence in the economy, and subjective wellbeing [2-6]. Despite its importance, trust in government has been declining in many developing and developed countries in recent years. During the COVID-19 pandemic, the Edelman Trust Barometer 2021 indicated that the level of trust in government dropped 8 points from May 2020 to January 2021-the lowest descent compared to other institutions such as media, NGOs, and business [7].

The eroding of trust is also indicated in the World Values Survey (WVS); the number of survey respondents who express high and relatively high trust in government dropped from $44.7 \%$ in Wave 6 (2010-2014) to $41.5 \%$ in Wave 7 (2017-2020). Additionally, comparing 2019 to the previous year, the Gallup World Poll (GWP) shows erosion of trust in government in many countries such as Chile $(-54 \%)$, Ecuador $(-48 \%)$, Costa Rica $(-41 \%)$, Slovakia $(-30 \%)$, Belgium $(-26 \%)$, and Thailand $(-23 \%)$. This decline of trust may threaten countries' capacity to tackle some of the key challenges for inclusive growth and wellbeing. The drop of trust perhaps explains the economic crises in some countries, and the damage could be persistent for generations even after economic recovery [8].

In economics, trust is similar to a public good in that it is non-tradable with no market price [9]. Accordingly, the market typically undersupplies it, even though it provides positive externalities to society. Therefore, being able to find the monetary proxy of trust is very important for public policy decision-making. To further clarify this statement, when allocating scarce public resources, cost-benefit analysis is carried out to compare the 
social and economic efficiency of policies. Consequently, insufficient measurement of the non-monetized value of trust will lead policy-makers to misestimate the cost of mistrust and the benefit when the trust level increases.

Instead of conducting non-market valuation methods using revealed or stated preference approaches, this study employs an alternative method named the Wellbeing Valuation Approach (WVA) to evaluate a shadow price. The WVA technique is conducted by estimating the income required to impact subjective wellbeing equally as a change in non-market goods [10]. Although the revealed and stated preference methods are broadly used to generate shadow price, Fujiwara and Campbell point out that the WVA is preferable over both the stated and revealed preference because of its cost-effectiveness, fewer survey-related biases, and fewer market structure assumptions [11].

In order to generate the shadow price of trust in government using the WVA, firstly the relationship between trust and subjective wellbeing has to be investigated. It is suggested that trust in government may influence citizens' subjective wellbeing, since confidence in government is primarily represented by the delivery quality of governmental services, and individuals who experience poor or unfair public services are more likely to be discontent in their life [4]. Previous research has shown substantial evidence for a positive relationship between trust in government and subjective wellbeing $[4,5,12]$, whereas the monetary size of trust in government remains unidentified.

In this study, we analyze a cross-country panel data set including 97 countries derived from the Gallup World Poll (GWP), the World Bank, and the International Monetary Fund over the period from 2011 to 2019 in order to accomplish three main objectives. The first is to investigate the relationship between trust in national government and national average life satisfaction. The second is to distinguish the direct effect of trust on national life satisfaction and the indirect effect of trust on the country's income. The third is to estimate a monetary value for trust in government using the application of the WVA approach. The main contribution of this study is to illustrate the effect of trust in government on subjective wellbeing and calculate the value of trust. The valuation can also be utilized as a financial proxy to evaluate the cost and benefit for the public and make prudent resource allocation decisions in order to increase trust in government.

The rest of the paper is organized as follows: Section 2 presents a literature review of trust measurements and the relationships between trust and subjective wellbeing, Section 3 presents the methodology and outlines the data and variables, Section 4 presents the empirical analysis results, discussions are set out in Section 5, and the final section summarizes our main findings.

\section{Literature Review}

Trust is defined as "a person's belief that another person or institution will act consistently with their expectations of positive behavior" [1]. Trust can be categorized into two main categories: interpersonal trust and institutional trust. This study focuses on the latter. Institutional trust may refer to citizens' trust in government, political institutions, police, judicial systems, and education systems. Public trust in government is explained in terms of citizens' satisfaction with their government. It is generally defined as a combination of perceptions of and attitudes toward a government's effectiveness in solving problems, addressing social and economic threats, and being fair, honest, and truthful [13]. Trust in the national government is often measured by conducting attitudinal surveys, asking citizens' opinions related to how much trust they have in their national government (ordinal answer scale) or whether they trust the government (binary answer scale).

The critical issue explaining why governments should pay more attention to tracking their confidence indicator is that it can explain why citizens are more willing to change their behavior to support desired policy outcomes. For example, trust in government was an essential factor in citizens' compliance with public health policies during the COVID-19 pandemic [14]. Especially during the pandemic, trust played a proactive role against systemic shocks [15]. Furthermore, it can support confidence in the economy and reduce 
enforcement and transaction costs [16]. The level of trust in national government depends on the expectations of citizens and government performance, which is described by the level of reliability, responsivity, and fairness of a government as viewed by citizens [1,17].

Institutional trust can be categorized based on political and non-political points of view, such as trust in the legal system, parliament, and politicians or trust in banking and healthcare. A wide range of previous empirical research $[3-5,18,19]$ attempts to investigate a relationship between institutional trust and subjective wellbeing; however, research focusing specifically on the influence of trust in government on subjective wellbeing is comparatively limited. A notable study by Hudson focuses mainly on the relationship between trust in government and subjective wellbeing using the data of 15 countries of the European Union [4]. The result shows that trust in the national government positively impacts subjective wellbeing. The same positive relationship result is also shown in the study of Macchia and Plagnol, as well as that of Kalsoom et al. [5,12]. The former estimation uses data from the Gallup World Poll across ten South American countries. The latter uses the data from the sixth wave of the World Values Survey 2010-2014 of ten Asian countries.

Political variables are highly relevant to subjective wellbeing and economic outcomes. For example, the study of Welsch uses Seemingly Unrelated Regression (SUR) to investigate the joint system equations [20]. The result shows that corruption directly affects subjective wellbeing and indirectly affects wellbeing through a decline in national income. The positive impact of trust on economic development has long been studied [21-23]. It is considered an essential factor in economic growth and functions as an engine to make economic exchange operate more efficiently and smoothly [24]. As a result, high trust in government could facilitate economic decisions and attract an increase in investment, since a favorable environment for business has been created, thus increasing economic growth.

Although the relationship between trust in government and wellbeing has been proven by evidence in the previous literature, very little research directly examines the monetary valuation of trust in government using the WVA technique. As far as we could find, the only equivalent studies are from Orlowski and Wicker and Hamilton et al. [25,26]. The former study uses data from the European Values Survey covering 45 European countries to evaluate institutional trust's monetary value. The result shows that, on average, a one standard deviation increase in institutional trust is worth an extra $€ 7405$ per year in terms of foregone income. The latter uses data of 132 countries from the Gallup World Poll and finds that social trust valuation is considerably large, ranging from $12-28 \%$ of total wealth, and its value also differs among world regions. To our knowledge, no study to date has yet monetized the welfare benefit of trust in government in a global scope with the WVA method.

The growing use of the WVA method in recent decades has resulted in a wider variety of research applications, including both environmental outcome evaluation [26-30] and social assessments such as healthy behavior, social capital, and cultural goods [27-30]. As suggested by Fujiwara et al., although the typical techniques are widely used to evaluate non-market goods and services, some limitations are worth mentioning [10]. Stated preference methods are considered to face the hypothetical bias, willingness to pay (WTP)-willingness to accept (WTA) disparity, and survey-related biases. Research using revealed preference methods is more cost-effective than the stated preference technique; however, the disadvantage of revealed preference methods is an inability to measure non-use values, especially since market imperfections can distort the estimated monetary value of non-market goods and services. Alternatively, the WVA method typically involves conducting econometric analysis using rich data sets containing subjective wellbeing, income, and non-market goods variables. Therefore, the WVA method provides fewer survey-related biases and market structure assumptions, and it is more cost-effective if the wellbeing data already exist. Fernandez mentions that the WVA is a potential complementary technique for valuing goods and services that are not able to be traded on the market [31]. 
In all, trust valuation has faced many challenges. This paper provides novel findings by applying the WVA to measure the monetary valuation of trust in government and hopes to be a good reference for a country's public policy decision-making, particularly during the COVID-19 pandemic period.

\section{Data and Methodology}

\subsection{Data}

The empirical analysis is based on three data sources: the World Happiness Report (WHR) by the Gallup World Poll (GWP), the World Development Indicator (WDI) by the World Bank, and the International Monetary Fund (IMF). We use a cross-country panel data set for 97 countries during the period covering 2011-2019 (9 years). The data are a panel of 873 observations. Although GWP provides data from 2005 to 2019, this study restricts the data set to the period from 2011-2019 because of data unavailability in some countries.

In this paper, we use life satisfaction as a measure of subjective wellbeing. The average life satisfaction level is measured with the Cantril ladder question [32], asking respondents to imagine their current position on a metaphorical ladder on a scale of 0-10. A response of 10, the top of the ladder, symbolizes having the best possible life. A response of 0 , the bottom of the ladder, represents having the worst possible life. The distinctive advantage of using the Cantril ladder question is that it provides a self-anchor scale based on each respondent's experience and perspective, which has shown to be a valid and reliable measure [33]. In addition, it reflects overall life more than an emotional component, and as such, it is more stable over the long term [34].

The primary independent variable is confidence in national government, which is measured as a percentage of respondents of each country reporting having confidence in the national government. After that, the percentage is rescaled to a unit value ranging from 1-10 in order to reduce collinearity between other dependent variables. The trust value of one represents the lowest trust, and ten represents the highest trust level. We choose GDP per capita in purchasing power parity (PPP) adjusted to constant 2017 international dollar (Intl\$) as an income variable proxy. It is said that GDP measured in international dollars provides a valid measure to compare prices and currency values between countries [35]. Further variable definitions and descriptive statistics used in the analysis are given in Table 1.

Table 2 presents the change in confidence in government by country, comparing the year 2019 to the previous year. There are 27 of 94 sample countries that reveal improving trust levels (data from Cambodia, Egypt, and Tajikistan are missing for the years 2018-2019). El Salvador experienced the most trust improvement with an increase of four percentage points, followed by Ukraine with three points, and seven countries experienced a two-point change. By contrast, trust in government deteriorated in 25 countries. Two-point negative change is shown in four countries: Chile, Costa Rica, Ecuador, and Thailand.

Before conducting the life satisfaction model, we begin the primary investigation of the effect of confidence in government on life satisfaction with a graphical representation. Figure 1 presents the cross-country correlation between life satisfaction and confidence in government by income level. A significant positive trend in the relationship between life satisfaction and confidence in government is illustrated only in high-income countries $(\mathrm{t}$-stat $=16.65)$. However, the relationship shows a negative trend in the low and middleincome groups ( $\mathrm{t}$-stat $=-6.13$ ). In the next section, we consider other relevant factors that are likely to influence life satisfaction level to form the life satisfaction model. 
Table 1. Descriptive statistics.

\begin{tabular}{|c|c|c|c|c|c|c|c|c|}
\hline Variable & Symbol & Description & Unit & Mean & SD & Min & Max & Source \\
\hline $\begin{array}{c}\text { Life } \\
\text { Satisfaction }\end{array}$ & W & Average life satisfaction level & {$[0,10]$} & 5.53 & 1.12 & 2.38 & 7.86 & GWP \\
\hline GDP & $\mathrm{y}$ & GDP per capita, PPP (constant 2017) & Intl\$ & 20,992 & 19,039 & 977 & 114,482 & $\begin{array}{l}\text { World } \\
\text { Bank }\end{array}$ \\
\hline $\begin{array}{l}\text { Confidence in } \\
\text { National } \\
\text { Government }\end{array}$ & $\mathrm{g}$ & $\begin{array}{l}\text { Average confidence in national } \\
\text { government level }\end{array}$ & {$[1,10]$} & 5.10 & 1.82 & 1.00 & 10.00 & GWP \\
\hline Social Support & support & $\begin{array}{l}\text { Share of individuals responding that } \\
\text { they have relatives or friends that } \\
\text { they can count on }\end{array}$ & $\%$ & 0.82 & 0.11 & 0.42 & 0.99 & GWP \\
\hline Choices & choice & $\begin{array}{l}\text { Share of individuals responding that } \\
\text { they are satisfied with their freedom } \\
\text { to choose what to do with their life }\end{array}$ & $\%$ & 0.76 & 0.13 & 0.33 & 0.96 & GWP \\
\hline Generosity & genero & $\begin{array}{l}\text { Residual of regressing the national } \\
\text { average of respondents donating } \\
\text { money to a charity in the past month }\end{array}$ & $\%$ & -0.01 & 0.16 & -0.33 & 0.55 & GWP \\
\hline $\begin{array}{l}\text { Human Capital } \\
\text { Index }\end{array}$ & $\mathrm{HCI}$ & $\begin{array}{c}\text { Combination of health and education } \\
\text { indicators }\end{array}$ & {$[0,1]$} & 0.59 & 0.15 & 0.29 & 0.85 & $\begin{array}{l}\text { World } \\
\text { Bank }\end{array}$ \\
\hline $\begin{array}{l}\text { Capital Stock } \\
\text { per Capita }\end{array}$ & $\mathrm{k}$ & $\begin{array}{l}\text { Per capita general government } \\
\text { capital stock and private capital stock }\end{array}$ & $\begin{array}{l}\text { Person } \\
\text { per } \\
\text { billions } \\
\text { Intl\$ }\end{array}$ & 46,034 & 46,675 & 1312 & 237,450 & IMF \\
\hline
\end{tabular}

Note: The natural logarithm of life satisfaction, confidence in national government, GDP, Human Capital Index, and capital stock per capita are used for the estimations. ${ }^{1}$ Human Capital Index is available only for 2010, 2017, 2018, and 2020. To match this report's sample periods, we use data in 2017 to represent the missing periods (2012-2016).

Table 2. Change in confidence in government by country from 2018 to 2019.

\begin{tabular}{|c|c|c|c|}
\hline Change & Freq. & Percent & Country Name \\
\hline-2 & 4 & $4 \%$ & Chile, Costa Rica, Ecuador, Thailand \\
\hline-1 & 21 & $22 \%$ & $\begin{array}{l}\text { Albania, Belgium, Bosnia and Herzegovina, Botswana, Cameroon, Canada, Ghana, Indonesia, Ireland, } \\
\text { Lebanon, Macedonia, Mali, Philippines, Portugal, Romania, Slovakia, South Africa, Tunisia, the United } \\
\text { Kingdom, Zambia, Zimbabwe }\end{array}$ \\
\hline 1 & 18 & $19 \%$ & $\begin{array}{c}\text { Austria, Burkina Faso, Colombia, Congo (Brazzaville), Finland, Georgia, Hungary, Japan, Kyrgyzstan, } \\
\text { Latvia, Lithuania, Mauritania, Moldova, Montenegro, Senegal, Slovenia, Spain, Sweden }\end{array}$ \\
\hline 2 & 7 & $7 \%$ & Brazil, Greece, Madagascar, Mexico, Nicaragua, Panama, Uruguay \\
\hline 3 & 1 & $1 \%$ & Ukraine \\
\hline 4 & 1 & $1 \%$ & El Salvador \\
\hline Total & 94 & $100 \%$ & \\
\hline
\end{tabular}

Note: Trust level of 42 countries (44\% total sample) remain unchanged. Data from three countries are missing for the years $2018-2019$.

\subsection{Methodology: The Wellbeing Valuation Approach (WVA)}

In order to determine the monetary value of trust in government, we need to estimate the effect that trust in government and income have on life satisfaction. The life satisfaction and income models are constructed in the first step, and the estimated coefficients obtained from the models are used to calculate the monetized value of trust in government. In this paper, wellbeing is defined as life satisfaction, and the life satisfaction model will be constructed based on the study of Helliwell et al. [36]. Our empirical strategy mainly follows the studies of Welsch, Fujiwara and Campbell, and Powdthavee and Van Den Berg $[11,20,27]$. 


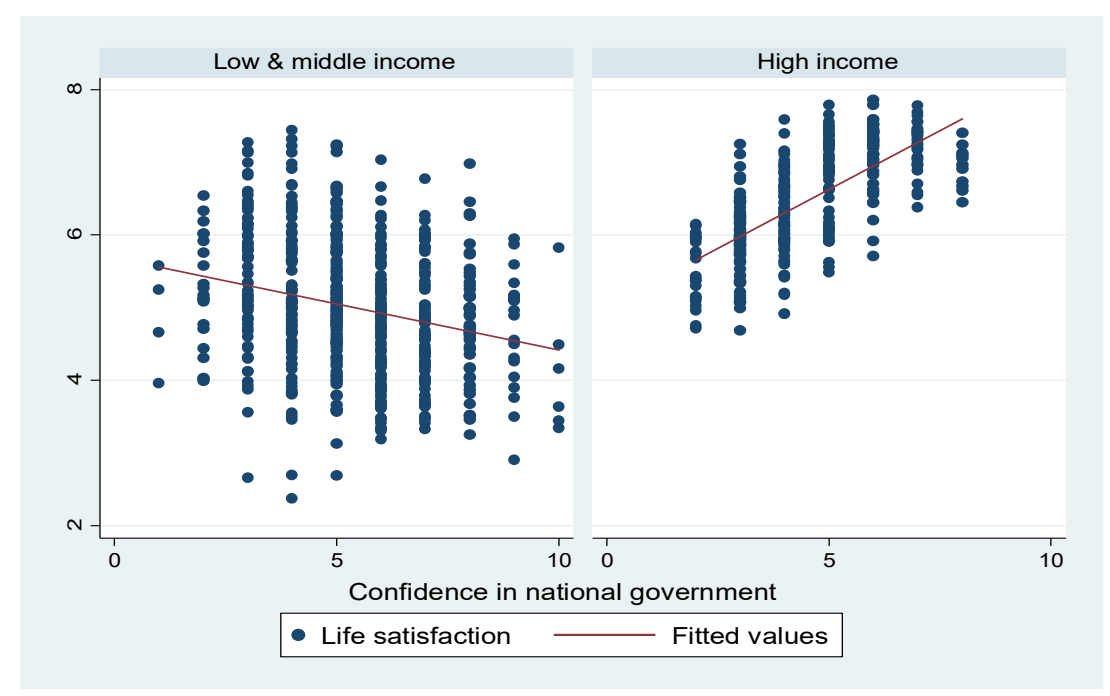

Figure 1. Correlation between life satisfaction and confidence in national government, 2011-2019.

\subsubsection{Model 1: The Life Satisfaction Model}

The WVA assumes that a monetary value should reflect the change in wellbeing due to experiencing a change in trust in government. The effect of income on national life satisfaction can be presented as follows:

$$
\ln \left(W_{i t}\right)=u\left(\ln \left(y_{i t}\right), \ln \left(g_{i t}\right), x_{i t}\right)
$$

where $W_{i t}$ represents wellbeing or life satisfaction level for country $i$ in period $t$. The $u($. function denotes the country's actual wellbeing, which is observable only through the aggregate number of the individuals asked. $y_{i t}$ is GDP per capita for country $i$ at time $t$. $g_{i t}$ is the level of confidence in national government, and $x_{i t}$ includes time-varying controls or other variables that tend to affect a country's life satisfaction level, such as social support, freedom to choose what to do in life, and generosity.

\subsubsection{Model 2: The Income Model}

According to the mediation hypothesis, we assume that government trust directly affects cross-national life satisfaction and indirectly affects life satisfaction through a decline in GDP. The income equation is written as follows:

$$
\ln \left(y_{i t}\right)=f\left(\ln \left(H C I_{i t}\right), \ln \left(k_{i t}\right), \ln \left(g_{i t}\right)\right.
$$

where $H C I_{i t}$ is the Human Capital Index for country $i$ in period $t$. The index is combined from health and education indicators that a child can expect to obtain by their 18th birthday. The variable $k_{i t}$ represents capital stock per capita for country $i$ at time $t$, which is the combination of general government capital stock and private capital stock; it is constructed based on general and private investment flows. $g_{i t}$ is the level of confidence in national government.

The income equation above is set by following the fundamental economic growth model of Solow and Lucas [37,38], namely the Human Capital Growth Model, which assumes that GDP varies across countries depending on their physical and human capital stock. Previous research discovered physical capital accumulation could be a primary engine for economic growth during the development process $[37,38]$. However, the importance granted to human capital through investment in education and health is indicated as a source of long-term economic growth [39,40]. The reduced form of Equation (3) is presented from substituting Equation (2) into Equation (1):

$$
\ln \left(W_{i t}\right)=u\left(f\left(\ln \left(H C I_{i t}\right), \ln \left(k_{i t}\right), \ln \left(g_{i t}\right)\right), \ln \left(g_{i t}\right), x_{i t}\right)
$$


To obtain the monetary value of confidence in government, the parameters needed to calculate monetary units are taken from the life satisfaction models and income models. The derivative of life satisfaction with respect to trust in government provides the total marginal welfare effect of trust in government $(d \ln (w) / d \ln (g))$. We then define the total effect as the combination of the direct $(\partial u / \partial \ln (g))$ and indirect marginal effect $((\partial u / \partial \ln (y)) \times(\partial f / \partial \ln (g)))$. Next, the monetized marginal welfare effect can be calculated by dividing by the marginal welfare effect of income $(\partial u / \partial \ln (y))$. The value of the level of confidence in national government can be estimated from the derivatives as follows:

$$
\text { Monetized effect }=\frac{d \ln (w) / d \ln (g)}{\partial u / \partial \ln (y)}=\frac{\partial u / \partial \ln (g)}{\partial u / \partial \ln (y)}+\frac{\partial f}{\partial \ln (G)}
$$

The monetary valuation of trust in government can be determined by estimating the following empirical counterpart to Equations (1) and (2). Moreover, variables are entered in logarithmic form for practical reasons, as the coefficient of the econometric model can be explained as the elasticity between trust and wellbeing.

$$
\begin{gathered}
\ln \left(w_{i t}\right)=\beta_{0}+\beta_{1} \ln \left(y_{i t}\right)+\beta_{2} \ln \left(g_{i t}\right)+\beta_{3} x_{i t}+\mu_{1 i}+\varepsilon_{1 i t} \\
\ln \left(y_{i t}\right)=\alpha_{0}+\alpha_{1} \ln \left(H C I_{i t}\right)+\alpha_{2} \ln \left(k_{i t}\right)+\alpha_{3} \ln \left(g_{i t}\right)+\mu_{2 i}+\varepsilon_{2 i t}
\end{gathered}
$$

Notice that per capita income is presented in logarithmic form according to the diminishing marginal utility of income [41]. $\mu_{i}$ is the country-specific error component, and $\varepsilon_{i t}$ is the disturbance term. The shadow price of confidence in government can be calculated using the concept of the marginal rate of substitution between income and confidence in government using the coefficients $\beta_{2}$ and $\beta_{1}$ from the life satisfaction model and $\alpha_{3}$ from the income model. The shadow price is calculated using the concept of Equivalent Variation (EV): the amount of additional income needed to restore an individual's original level of utility if the trust level has decreased.

Equations (5) and (6) can be estimated equation-by-equation using standard panel data models. Such estimates are consistent but generally not as efficient. The Seemingly Unrelated Regression (SUR) technique is proposed by Zellner [42], which uses generalized least-square estimation for a set of equations that are seemingly related through their disturbance, and the error terms are assumed to be correlated across the equations. Before applying this technique, joint hypothesis testing needs to be considered. We need to perform the joint test $\beta_{2}=\alpha_{3}=0$, and investigate the correlation of the errors terms $u_{1}$ and $u_{2}$. If the errors are correlated, SUR (which treats the equations as a system) will contribute efficiency gains over the equation-by-equation estimation [43].

However, when the error terms are uncorrelated between the equations (so that they are truly unrelated) and when each equation contains exactly the same set of regressors on the right-hand side, then the SUR is equivalent to the panel data model. Therefore, if the null hypothesis of the coefficients jointly equaling to zero $\left(\beta_{2}=\alpha_{3}=0\right)$ in both equations on trust in government cannot be rejected, then Equations (5) and (6) can be estimated separately using the panel data estimation methods. An advantage of a panel data set is that it provides more flexibility in modeling differences in behavior across individuals and allows us to control country-specified factors or variables that change over time but not across countries [44]. The distinction between fixed-effect (FE) and random-effect (RE) models is whether the unobserved individual effect embodies elements correlated with the model's repressors, not whether these effects are stochastic. Hausman test is applied to investigate whether FE or RE is more efficient.

\section{Empirical Results}

\subsection{Life Satisfaction and Income Models}

Table 3 presents the results estimated by SUR, RE, and FE models. The SUR regression explains that the total effect of trust in government on life satisfaction can be decomposed into direct and indirect effects. The direct effect is the effect of trust in government on life 
satisfaction. The indirect effect channel is the effect of trust on life satisfaction that works through per capita income.

Table 3. Life satisfaction and income models, 2011-2019.

\begin{tabular}{|c|c|c|c|}
\hline & SUR (1) & RE (2) & FE (3) \\
\hline \multicolumn{4}{|l|}{ Life Satisfaction Model (Direct Effect) } \\
\hline \multirow[t]{2}{*}{ Ln (Confidence in government) } & $0.046^{* * *}$ & $0.036^{* * *}$ & $0.053^{* * *}$ \\
\hline & [0.015] & {$[0.014]$} & {$[0.015]$} \\
\hline \multirow[t]{2}{*}{ Ln (Per capita GDP) } & $0.176^{* * *}$ & $0.120^{* * *}$ & $0.228^{* * *}$ \\
\hline & {$[0.068]$} & {$[0.010]$} & {$[0.060]$} \\
\hline \multirow[t]{2}{*}{ Social support } & $0.335^{* * *}$ & $0.379^{* * *}$ & $0.328^{* * *}$ \\
\hline & [0.069] & {$[0.063]$} & {$[0.071]$} \\
\hline \multirow[t]{2}{*}{ Freedom of choice } & 0.02 & $0.153^{* * *}$ & 0.044 \\
\hline & [0.055] & {$[0.048]$} & {$[0.055]$} \\
\hline \multirow[t]{2}{*}{ Generosity } & 0.06 & $0.158^{* * *}$ & $0.164^{* * *}$ \\
\hline & [0.046] & [0.037] & {$[0.044]$} \\
\hline \multirow[t]{2}{*}{ Constance } & -0.383 & 0.087 & -0.833 \\
\hline & {$[0.622]$} & {$[0.083]$} & [0.541] \\
\hline Controlling year & yes & yes & yes \\
\hline Controlling country & yes & & \\
\hline Prob (F-statistic) & 0.000 & 0.000 & 0.000 \\
\hline Haman Test ( $P$-value $)$ & & 0.002 & \\
\hline Observation & 624 & 847 & 847 \\
\hline R-squared & 0.916 & 0.700 & 0.662 \\
\hline \multicolumn{4}{|l|}{ Income Model (Indirect Effect) } \\
\hline \multirow[t]{2}{*}{ Ln (Human Capital Index) } & -0.07 & $0.567^{* * *}$ & -0.069 \\
\hline & {$[0.087]$} & {$[0.099]$} & [0.095] \\
\hline \multirow[t]{2}{*}{ Ln (Government and private capital stock) } & $0.112 * * *$ & $0.269 * * *$ & $0.113^{* * *}$ \\
\hline & {$[0.013]$} & {$[0.013]$} & {$[0.015]$} \\
\hline \multirow[t]{2}{*}{ Ln (Confidence in government) } & $0.041^{* * *}$ & $0.039^{* * *}$ & $0.041^{* * *}$ \\
\hline & {$[0.008]$} & {$[0.010]$} & {$[0.008]$} \\
\hline \multirow[t]{2}{*}{ Constance } & $7.143^{* * *}$ & $4.716^{* * *}$ & $7.224^{* * *}$ \\
\hline & {$[0.260]$} & {$[0.273]$} & {$[0.283]$} \\
\hline Controlling year & yes & yes & yes \\
\hline \multicolumn{4}{|l|}{ Controlling country } \\
\hline Prob (F-statistic) & 0.000 & 0.000 & 0.000 \\
\hline Haman Test $(P$-value $)$ & & 0.000 & \\
\hline Breusch-Pagan test (Chi-square) & 0.017 & & \\
\hline Observation & 624 & 627 & 627 \\
\hline R-squared & 0.999 & 0.937 & 0.893 \\
\hline
\end{tabular}

Note: Standard errors are presented in parentheses. ${ }^{*}, * *$, and ${ }^{* * *}$ denote significance at $10 \%, 5 \%$, and $1 \%$, respectively.

As shown in Table 3, the R-squared value of life satisfaction models ranges from $0.66-0.92$, meaning that more than half of the observed variation can be explained by the model's independent variables. Turning to the income equation, the three variables (trust in government, Human Capital Index, government and private capital stock) explain more than $90 \%$ of the variation in per capita GDP among countries. The high R-squared value of the income model is consistent with the research results of Welsch and Senhadji $[20,45]$, which show an R-squared value of over $80 \%$ for OECD countries. The F-statistic in all models indicates that the set of coefficients differs from zero, meaning that the independent variables can describe the dependent variables. We first assess multicollinearity issues in the regressions (see Table A1 in Appendix A).

Despite social support and GDP showing a correlation of 0.71 , the Variance Inflation Factor (VIF) provides a mean value of 1.80, indicating that there is only a slight to moderate correlation between explanatory variables. This implies that the issue of multicollinearity is not significantly problematic for the analysis. After that, we test the null hypothesis of zero correlation between life satisfaction and income equations. The chi-square value of 
the Breusch-Pagan test equals $0.017(P$-value $=0.897)$, which is not sufficient to reject the null hypothesis of zero correlation between two equations. Therefore, the life satisfaction and income models can be estimated separately using panel data estimation methods of fixed-effect $(\mathrm{FE})$ or random-effect $(\mathrm{RE})$ regression. Another reason explaining why RE or FE is preferred over SUR is that the data used in this study consist of a large number of cross-sectional units ( $\mathrm{N}=97$ countries) and a small number of time-series observations ( $\mathrm{T}=9$ years). However, the SUR estimator is based on large $\mathrm{T}$ and small $\mathrm{N}$, and it requires that the T observations per unit must exceed $\mathrm{N}$ [46]. Although SUR estimation cannot provide better efficiency, we also present the SUR results for reference. Next, we conducted the Hausman test to decide whether FE or RE model should be applied. The test results rejected the null hypothesis, which means FE is more efficient than RE. Fixed-effect estimations may also help eliminate initial differences across countries and reduce endogeneity problems [47].

Overall, the empirical findings confirm a positive and significant link between confidence in government and life satisfaction level. The coefficients in a log-log model represent the elasticity of life satisfaction with respect to per capita income and trust in government, which shows as relatively low or inelastic. It can be explained that a 1 percent increase in trust in government is associated with a 0.053 percent (column 3 ) increase in national life satisfaction, on average, and a 1 percent rise in per capita income is associated with a 0.228 percent rise in national life satisfaction. The other factors positively explaining life satisfaction are GDP per capita, social support, and generosity. Moving on to the income model, the result shows that trust in government and both government and private capital are positively and significantly related to GDP. However, the Human Capital Index shows no statistical significance when controlling for the country-specific effect. A possible explanation for this insignificant result is the low variation in the Human Capital Index.

We also provide a robustness check (see Table 4) to further investigate whether the estimated relationship between trust in government and life satisfaction is robust across country income groups. The coefficient of trust and income are significate for both the high-income and the low- and middle-income groups; however, the magnitude of the effect of trust on life satisfaction is greater for the high-income group. Furthermore, due to the small sample size when splitting observations into two groups, we still cannot assume that the paired coefficients are different from each other across the subgroups. In conclusion, the robustness checks across all alternative estimations and subgroups provide robust empirical findings of positive and significant links between confidence in government, GDP, and life satisfaction.

\subsection{The Monetary Value of Trust in National Government}

The WVA is conducted to identify the monetized effect of trust by estimating the change in income required to equivalently affect subjective wellbeing compared to a change in governmental trust. To obtain the monetary value of trust in government, the parameters needed to calculate monetary units are taken from the life satisfaction and income models of the FE estimation shown in Column 3 of Table 3. Note that the monetized effect will be computed for each country and year from 2011 to 2019. Table 5 presents the marginal effects and monetary value percentiles. The median value (the 50 th percentile) of the total marginal effect implies that if $50 \%$ of the observations increase in trust by one point, the life satisfaction will increase by more than 0.063 . At this 50th percentile point, trust in government is valued at Int $\$ 5649$ per person per year (the detailed explanation on how to calculate the monetary value of trust in government can be found in Appendix B), $85 \%$ of which is from the direct effect. It should be noted that the estimated monetary value of trust in government is driven largely by the high-income sub-sample, which accounts for $36 \%$ of the observations, whereas only $10 \%$ are from the low-income countries. The significance of the monetary equivalents highlights that when there is any welfare loss subject to the drop in trust in government, people, on average, tend to be willing to pay more to avoid moving to this worse situation. 
Table 4. Life satisfaction and income models by country income groups, 2011-2019.

\begin{tabular}{|c|c|c|c|c|}
\hline & \multicolumn{2}{|c|}{ Low and Middle Income } & \multicolumn{2}{|c|}{ High Income } \\
\hline & SUR & FE & SUR & FE \\
\hline \multicolumn{5}{|l|}{ Life Satisfaction Model } \\
\hline \multirow[t]{2}{*}{ Ln (Confidence in government) } & $0.046^{* *}$ & $0.049^{* *}$ & $0.051^{* * *}$ & $0.057^{* * *}$ \\
\hline & {$[0.023]$} & {$[0.023]$} & {$[0.013]$} & {$[0.012]$} \\
\hline \multirow[t]{2}{*}{ Ln (Per capita GDP) } & $0.192 *$ & $0.263^{* * *}$ & $0.149^{* *}$ & $0.168^{* * *}$ \\
\hline & [0.104] & {$[0.087]$} & {$[0.060]$} & {$[0.052]$} \\
\hline \multirow[t]{2}{*}{ Social support } & $0.315^{* * *}$ & $0.324^{* * *}$ & $0.493^{* * *}$ & $0.292 * * *$ \\
\hline & [0.089] & {$[0.094]$} & {$[0.112]$} & {$[0.091]$} \\
\hline \multirow[t]{2}{*}{ Freedom of choice } & -0.022 & 0.005 & $0.117^{*}$ & $0.196^{* * *}$ \\
\hline & [0.077] & {$[0.076]$} & {$[0.061]$} & [0.057] \\
\hline \multirow[t]{2}{*}{ Generosity } & 0.078 & $0.210 * * *$ & 0.051 & 0.071 \\
\hline & [0.068] & {$[0.066]$} & [0.045] & {$[0.044]$} \\
\hline \multirow[t]{2}{*}{ Constance } & -0.478 & -1.031 & -0.281 & -0.413 \\
\hline & [0.952] & {$[0.740]$} & [0.637] & {$[0.528]$} \\
\hline Controlling year & yes & yes & yes & yes \\
\hline \multicolumn{5}{|l|}{ Controlling country } \\
\hline Prob (F-statistic) & 0.000 & 0.000 & 0.000 & 0.000 \\
\hline Observation & 390 & 538 & 234 & 309 \\
\hline R-squared & 0.846 & 0.411 & 0.933 & 0.770 \\
\hline \multicolumn{5}{|l|}{ Income Model } \\
\hline \multirow[t]{2}{*}{ Ln (Human Capital Index) } & -0.123 & -0.123 & $0.306^{*}$ & 0.292 \\
\hline & [0.097] & {$[0.106]$} & {$[0.185]$} & {$[0.205]$} \\
\hline \multirow[t]{2}{*}{ Ln (Government and private capital stock) } & $0.069^{* * *}$ & $0.069^{* * *}$ & $0.206^{* * *}$ & $0.204 * * *$ \\
\hline & {$[0.018]$} & {$[0.019]$} & {$[0.021]$} & {$[0.023]$} \\
\hline \multirow{2}{*}{ Ln (Confidence in government) } & $0.033^{* * *}$ & $0.034^{* * *}$ & $0.062^{* * *}$ & $0.059 * * *$ \\
\hline & {$[0.010]$} & {$[0.011]$} & {$[0.011]$} & [0.012] \\
\hline \multirow[t]{2}{*}{ Constance } & $7.914^{* * *}$ & & $6.349^{* * *}$ & $6.25^{* * *}$ \\
\hline & [0.337] & & [0.460] & {$[0.496]$} \\
\hline Controlling year & yes & & yes & \\
\hline Controlling country & yes & & yes & \\
\hline Prob (F-statistic) & 390 & 390 & 234 & 236 \\
\hline Observation & 0.998 & 0.609 & 0.9930 & 0.6970 \\
\hline R-squared & 0.000 & 0.000 & 0.000 & 0.000 \\
\hline
\end{tabular}

Note: Standard errors are presented in parentheses, ${ }^{*}, * *$, and ${ }^{* * *}$ denote significance at $10 \%, 5 \%$, and $1 \%$, respectively.

Table 5. Marginal effects and monetary value of confidence in national government.

\begin{tabular}{ccccc}
\hline \multirow{2}{*}{ Percentile } & \multicolumn{3}{c}{ Marginal Welfare Effect } & \multirow{2}{*}{ Monetized Effect (Intl\$) } \\
\cline { 2 - 4 } & Direct & Indirect & Total & \\
\hline $1 \%$ & 0.023 & 0.004 & 0.027 & 187 \\
$5 \%$ & 0.029 & 0.005 & 0.034 & 324 \\
$10 \%$ & 0.032 & 0.006 & 0.038 & 442 \\
$25 \%$ & 0.043 & 0.008 & 0.050 & 1262 \\
$50 \%$ & 0.063 & 0.011 & 0.074 & 5649 \\
$75 \%$ & 0.084 & 0.015 & 0.099 & 14,226 \\
$90 \%$ & 0.109 & 0.019 & 0.128 & 20,074 \\
$95 \%$ & 0.128 & 0.023 & 0.151 & 22,703 \\
$99 \%$ & 0.162 & 0.029 & 0.191 & 29,682 \\
\hline
\end{tabular}

\section{Discussions}

This study finds that trust in national government is associated with average life satisfaction level, and the monetary value of trust in government has a global median value of Intl\$ 5649 per person a year. The positive relationship between trust in government and life satisfaction is in line with previous studies [4,5,12], and the large monetary value of trust implies that importance of building trust in government. A previous study conducted by 
OECD suggests that trust in government can be restored by reducing corruption, increasing transparency, such as budget and tax transparency, and strengthening citizens' voices and engagement [1].

It should be noted that the monetary values of public goods using the WVA might also be criticized on the basis of their large value compared to the revealed or stated preference approaches [25-27]. As is further explained by Welsch and Ferreira, there are two reasons behind this considerably larger value: (i) the endogeneity issues related to the income variable may bias the estimated coefficient; (ii) the WVA presents the long-term social value of income, while the revealed and stated preference methods tend to deliver a short-term evaluation [48]. Previous research [10] uses lottery wins as an instrument for household income, because it satisfies the requirement of an exogenous instrument by directly impacting income without correlating with the error term in the subjective wellbeing equation. However, with cross-country data, there are challenges in selecting proper exogenous instruments, since macroeconomic variables tend to correlate with both GDP and life satisfaction. Although ignoring the issue of the endogeneity of income may cause bias in coefficient estimates, Barros et al. suggest that in some research contexts, one way to deal with the endogeneity problem is to use panel data, since panel data can control the individual heterogeneity $[49,50]$.

\section{Conclusions}

This paper explores whether there is a relationship between trust in national government and national average life satisfaction and aims to evaluate trust in government. Using cross-country panel data for 97 countries in the period 2011 to 2019, we utilize the Wellbeing Valuation Approach (WVA) to estimate the monetized effect of trust in government.

Our empirical results highlight three findings. First, there is a positive relationship between trust in national government and national average life satisfaction. The coefficient has shown that a 1 percent increase in trust in government is associated with a 0.056 percent increase in national life satisfaction. Second, a one percent reduction in the average confidence in national government is equivalent, in subjective wellbeing, to Int $\$ 5649$ per person a year or Intl $\$ 470.8$ per month. Third, trust affects national life satisfaction, not only directly, but also indirectly through per capita GDP. However, the indirect marginal effect is considered relatively small, approximately six times smaller than the direct effect. The significant value of trust in government suggests that more attention should be paid to building governmental trust, since a lack of confidence is likely to damage the life satisfaction level of citizens. The contribution of the shadow price is also devoted to the social cost-benefit policy assessment area, since the value of trust in government can be used as a proxy to plan future investment or calculate a social impact assessment of trust policy.

However, our study is not without limitations. First, the financial proxy should be taken with caution, since the monetary value is estimated from national aggregate variables instead of using individual-level data. Therefore, the value only represents the median value of overall trust and cannot be applied to a specific country. Second, the link between trust in government and life satisfaction should be viewed in terms of correlation rather than as a causal effect, since the observations are limited by the availability of countries and years. Third, the endogeneity issues related to the income variable may affect the estimated coefficient. Further research must identify proper instrumental variables in order to provide a more robust estimation of the coefficient of income. Furthermore, as the data sets of national average life satisfaction across countries continue to increase, future research may be conducted using more cross-country panel data or individual panel data in order to determine the causal relationship.

Author Contributions: C.-L.C. conceived and designed the research and methodology; S.S. collected, managed, and verified the data; C.-L.C. and S.S. calculated and analyzed the data and results; S.S. wrote the manuscript; C.-L.C. review and editing the manuscript. Both authors have read and agreed to the published version of the manuscript. 
Funding: This research received no external funding.

Institutional Review Board Statement: Not applicable.

Informed Consent Statement: Not applicable.

Data Availability Statement: Publicly available datasets were analyzed in this study. This data can be found here: https://worldhappiness.report/, https:/ / databank.worldbank.org/source/worlddevelopment-indicators, https://www.imf.org/en/Home.

Conflicts of Interest: The authors declare no conflict of interest.

\section{Appendix A}

Table A1. Correlation between the explanatory variables.

\begin{tabular}{ccccc}
\hline & $\begin{array}{c}\text { Ln (Confidence in } \\
\text { Government) }\end{array}$ & $\begin{array}{c}\text { Ln } \\
\text { (Per Capita GDP) }\end{array}$ & Social Support & Freedom of Choice \\
\hline Gn (Confidence in & 1 & & & \\
government) & $-0.2737^{*}$ & 1 & & \\
Ln (Per capita GDP) & 0.000 & & & \\
Social support & $-0.1988^{*}$ & $0.7075^{*}$ & 0.000 & $0.3739 *$ \\
Freedom of choice & 0.000 & $0.3059 *$ & 0.000 & 1 \\
Generosity & $0.3953^{*}$ & 0.000 & $0.1385^{*}$ & $0.3713^{*}$ \\
\end{tabular}

Note: * denotes significance at $5 \%$.

\section{Appendix B \\ Monetary Value Calculation}

In order to calculate the monetary value of trust in government, we use the estimated coefficients of trust on life satisfaction $\left(\beta_{2}\right)$, the estimated coefficients of GDP on life satisfaction $\beta_{1}$, and the estimated coefficients of trust on GDP $\left(a_{3}\right)$, which are taken from Column 3 of Table 3.

Following the study of Welsch [20], the total effect of trust on wellbeing is assumed to be the combination of the direct and indirect effects. The direct and indirect marginal effect can be written as $\beta_{2} \times\left(W_{i t} / g_{i t}\right)$ and $\beta_{1} \times a_{3} \times\left(W_{i t} / g_{i t}\right)$, respectively. Meanwhile, we are interested in the proportion of the total effect that is due to the indirect effect. Then, for any single country and single year, the direct effect presents as proportional to 0.053 and indirect is proportional to $0.228 \times 0.041=0.0094$. Comparing these values, we see the indirect effect is relatively small compared to the direct effect. Both effects are combined to represent the total marginal effect which is calculated as $\left(\beta_{2}+\beta_{1} a_{3}\right) \times\left(W_{i t} / g_{i t}\right)=0.0624 \times\left(W_{i t} / g_{i t}\right)$. After that, to obtain the monetized effect, we need to divide the total marginal welfare effect of trust by the marginal welfare effect of income $\left(\beta_{1} / y_{i t}\right)$. Hence, the monetized effect is transformed to $\left(\beta_{2} / \beta_{1}+a_{3}\right) \times\left(W_{i t} / g_{i t}\right) \times y_{i t}$.

\section{References}

1. OECD. OECD Guidelines on Measuring Trust; OECD Publishing: Paris, France, 2017; ISBN 978-92-64-27820-2.

2. Macdonald, D. Trust in Government and the American Public's Responsiveness to Rising Inequality. Political Res. Q. 2020, 73, 790-804. [CrossRef]

3. Fu, X. The Contextual Effects of Political Trust on Happiness: Evidence from China. Soc. Indic. Res. 2018, 139, 491-516. [CrossRef]

4. Hudson, J. Institutional Trust and Subjective Well-Being across the EU. Kyklos 2006, 59, 43-62. [CrossRef]

5. Macchia, L.; Plagnol, A.C. Life Satisfaction and Confidence in National Institutions: Evidence from South America. Appl. Res. Qual. Life 2019, 14, 721-736. [CrossRef]

6. Dalton, R. The Social Transformation of Trust in Government. Int. Rev. Sociol./Rev. Int. De Sociol. 2005, 15. [CrossRef]

7. Edelman. Edelman Trust Barometer 2021. Available online: https://www.edelman.com/trust/2021-trust-barometer (accessed on 14 January 2021). 
8. Stiglitz, J.; Fitoussi, J.; Durand, M. (Eds.) For Good Measure: Advancing Research on Well-Being Metrics Beyond GDP; OECD Publishing: Paris, France, 2018; ISBN 978-92-64-30726-1.

9. Gambetta, D. Can We Trust Trust? In Trust: Making and Breaking Cooperative Relations; Gambetta, D., Ed.; Blackwell: Oxford, $\mathrm{UK}, 1988$.

10. Fujiwara, D.; Kudrna, L.; Dolan, P. Quantifying and Valuing the Wellbeing Impacts of Culture and Sport; Department for Culture Media and Sport: London, UK, 2014.

11. Fujiwara, D.; Campbell, R. Valuation Techniques for Social Cost-Benefit Analysis: Stated Preference, Revealed Preference and Subjective Well-Being Approaches: A Discussion of the Current Issues; HM Treasury: London, UK, 2011; ISBN 978-1-84532-899-3.

12. Kalsoom, R.; Yaseen, M.R.; Asif, A.; Sardar, A.; Quddoos, A. Impact of Institutional Trust on Subjective Well-Being in Selected Asian Countries. Proc. Pak. Soc. Dev. Econ. 2017, 33, 745-760.

13. Clarke, N.; Light, P.C. Global Trust in Government; The Volcker Alliance: New York, NY, USA, 2013.

14. Bargain, O.; Aminjonov, U. Trust and Compliance to Public Health Policies in Times of COVID-19. J. Public Econ. 2020, $192,104316$. [CrossRef]

15. OECD. Building Resilience to the COVID-19 Pandemic: The Role of Centers of Government. Available online: http: / / www.oecd.org/coronavirus / policy-responses/building-resilience-to-the-covid-19-pandemic-the-role-of-centres-ofgovernment-883d2961/ (accessed on 2 September 2020).

16. Dyer, J.H.; Chu, W. The Role of Trustworthiness in Reducing Transaction Costs and Improving Performance: Empirical Evidence from the United States, Japan, and Korea. Organ. Sci. 2003, 14, 57-68. [CrossRef]

17. OECD. OECD Guidelines on Measuring Subjective Well-Being; OECD Publishing: Paris, France, 2013; ISBN 978-92-64-19164-8.

18. Helliwell, J.F.; Huang, H.; Wang, S. New Evidence on Trust and Well-Being; NBER Working Paper 22450; National Bureau of Economic Research: Cambridge, MA, USA, 2016.

19. Zhao, D.; Zhang, Z. Changes in Public Trust in Physicians: Empirical Evidence from China. Front. Med. 2019, 13, 504-510. [CrossRef]

20. Welsch, H. The Welfare Costs of Corruption. Appl. Econ. 2008, 40, 1839-1849. [CrossRef]

21. Arrow, K. Limited Knowledge and Economic Analysis. Am. Econ. Rev. 1974, 64, 1-10.

22. Algan, Y.; Cahuc, P. Trust, Growth, and Well-Being: New Evidence and Policy Implications. In Handbook of Economic Growth; Elsevier: Amsterdam, The Netherlands, 2014; pp. 49-120.

23. Guo, Y.; He, S. Does Confidence Matter for Economic Growth? An Analysis from the Perspective of Policy Effectiveness. Int. Rev. Econ. Financ. 2020, 69, 1-19. [CrossRef]

24. Arrow, K.J. Gifts and Exchanges. Philos. Public Aff. 1972, 1, 343-362.

25. Orlowski, J.; Wicker, P. The Monetary Value of Social Capital. J. Behav. Exp. Econ. 2015, 57, 26-36. [CrossRef]

26. Hamilton, K.; Helliwell, J.F.; Woolcock, M. Social Capital, Trust and Well-Being in the Evaluation of Wealth; Policy Research Working Paper No. 7707; World Bank: Washington, DC, USA, 2016.

27. Powdthavee, N.; van den Berg, B. Putting Different Price Tags on the Same Health Condition: Re-Evaluating the Well-Being Valuation Approach. J. Health Econ. 2011, 30, 1032-1043. [CrossRef] [PubMed]

28. Saz-Salazar, S.; Navarrete-Tudela, A.; Alcalá-Mellado, J.R.; Saz-Salazar, D.C. On the Use of Life Satisfaction Data for Valuing Cultural Goods: A First Attempt and a Comparison with the Contingent Valuation Method. J. Happiness Stud. 2019, 20, 119-140. [CrossRef]

29. Okuyama, N. A Valuation of Viewing Public Broadcasting with Endogeneity: The Life Satisfaction Approach. Telecommun. Policy 2019, 43, 1-12. [CrossRef]

30. Shi, Y.; Joyce, C.; Wall, R.; Orpana, H.; Bancej, C. A Life Satisfaction Approach to Valuing the Impact of Health Behaviours on Subjective Well-Being. BMC Public Health 2019, 19, 1547. [CrossRef] [PubMed]

31. Fernandez, C.J.; Raitzer, D.; Ginting, E. Potential Use of the Life Satisfaction Approach to Value Nonmarket Goods and Services; ADB Working Paper No. 569; Asian Development Bank: Manila, Philippines, 2016.

32. Cantril, H. The Pattern of Human Concerns; Rutgers University Press: New Brunswick, NJ, USA, 1965.

33. Napoli, I.; Arcidiacono, C. The Use of Self-Anchoring Scales in Social Research: The Cantril Scale for the Evaluation of Community Action Orientation. In Survey Data Collection and Integration; Springer: New York, NY, USA, 2013; pp. 73-85. ISBN 978-3-64221307-6.

34. Helliwell, J.F.; Putnam, R.D. The Social Context of Well-Being. Philos. Trans. R. Soc. Lond. B 2004, 359, 1435-1446. [CrossRef]

35. Pilat, D.; Schreyer, P. Measuring Productivity: Measurement of Aggregate and Industry-Level Productivity Growth; OECD Manual; Statistics; OECD Publishing: Paris, France, 2003; ISBN 978-92-64-18737-5.

36. Helliwell, J.F.; Layard, R.; Sachs, J.; De Neve, J. World Happiness Report 2020; Sustainable Development Solutions Network: New York, NY, USA, 2020.

37. Nguyen, T.-A. Sources of Economic Growth: Physical Capital, Human Capital, Natural Resources, and TFP; Lap Lambert Academic: Riga, Latvia, 2012.

38. Everaert, G. Balanced Growth and Public Capital: An Empirical Analysis with I(2) Trends in Capital Stock Data. Econ. Model. 2003, 20, 741-763. [CrossRef]

39. Siddiqui, A.; Rehman, A.U. The Human Capital and Economic Growth Nexus: In East and South Asia. Appl. Econ. 2017, 49, 2697-2710. [CrossRef] 
40. Ogundari, K.; Awokuse, T. Human Capital Contribution to Economic Growth in Sub-Saharan Africa: Does Health Status Matter More than Education? Econ. Anal. Policy 2018, 58, 131-140. [CrossRef]

41. Easterlin, R.A.; McVey, L.A.; Switek, M.; Sawangfa, O.; Zweig, J.S. The Happiness-Income Paradox Revisited. Proc. Natl. Acad. Sci. USA 2010, 107, 22463-22468. [CrossRef] [PubMed]

42. Zellner, A. Estimators for Seemingly Unrelated Regression Equations: Some Exact Finite Sample Results. J. Am. Stat. Assoc. 1963, 58, 977-992. [CrossRef]

43. Bartels, R.; Fiebig, D.G. A Simple Characterization of Seemingly Unrelated Regressions Models in Which OLS Is BLUE. Am. Stat. 1991, 45, 137-140. [CrossRef]

44. Greene, W.H. Econometric Analysis, 5th ed.; Prentice Hall: Upper Saddle River, NJ, USA, 2002.

45. Senhadji, A. Sources of Economic Growth: An Extensive Growth Accounting Exercise; IMF Working Paper No. 9977; International Monetary Fund: Washington, DC, USA, 2000.

46. Wooldridge, J.M. Introductory Econometrics: A Modern Approach, 3rd ed.; International Student, Ed.; Thomson South-Western: Mason, OH, USA, 2006; ISBN 978-0-324-32348-1.

47. Levinson, A. Valuing Public Goods Using Happiness Data: The Case of Air Quality; Working Paper No. 15156; National Bureau of Economic Research: Cambridge, MA, USA, 2009.

48. Welsch, H.; Ferreira, S. Environment, Well-Being, and Experienced Preference. Int. Rev. Environ. Resour. Econ. 2014, 7, 205-239. [CrossRef]

49. Fortin, N.; Lemieux, T.; Firpo, S. Decomposition Methods in Economics. Handb. Labor Econ. 2011, 4, 1-102. [CrossRef]

50. Barros, L.A.B.C.; Bergmann, D.R.; Castro, F.H.; Silveira, A.M. Endogeneity in Panel Data Regressions: Methodological Guidance for Corporate Finance Researchers. Rev. Bras. Gestão Negócios 2020, 22, 437-461. [CrossRef] 